\title{
Organizational Affiliation Name
}

National Cancer Institute

\section{Source}

National Cancer Institute. Organizational Affiliation Name. NCI Thesaurus. Code

C154704.

The name of the organization or entity that the person or group has an established relationship with. 